\title{
Designing Educational Events in an Online Format
}

\author{
Marina Nikolaeva ${ }^{1}$, Nelly Shramko ${ }^{1}$, Anastasiya Pesha ${ }^{2, *}$ \\ ${ }^{1}$ Ural State Pedagogical University, Yekaterinburg, 620012, Russia \\ ${ }^{2}$ Ural State University of Economics, Yekaterinburg, 620144, Russia \\ *Corresponding author.Email: myrabota2011@gmail.com.
}

\begin{abstract}
Education for Sustainable Development (ESD) and sustainable development of the education system are an important part of the sustainable development strategy. Universities whose activities are aimed at training specialists are an important subject of the transmission of knowledge in the field of sustainable development. Students are the guarantor of the future environmental and economic sustainability of the region, country and world. It is important to update the didactic tools used in teaching and introduce new forms of organizing the educational process. The potential for organizing pedagogical activities through the implementation of educational events is high, since it focuses on project and team work, and also uses the capabilities of the information educational environment. The paper presents the stages of designing a specific educational event, showing its results. The practical significance lies in the fact that this form of organization of activities makes it possible to individualize the learning process, to ensure equal attention to the development of professional and supra-professional competencies of students.
\end{abstract}

Keywords: individualization, supra-professional competencies, Education for Sustainable Development (ESD), educational event, online format, event-driven approach.

\section{INTRODUCTION}

The urgency of this problem is due to a number of circumstances. On the one hand, the topic of higher education for sustainable development has been widely developed in the scientific community in recent years. We tend to agree with the opinion of E. M. Waltner, K. Scharenberg, C. Hörsch \& W. Rieß. The fact that education for sustainable development is a system of actions to develop students' competence for sustainable development [1].

The UNESCO document "Education for Sustainable Development Goals" presents a number of key transversal competencies that ensure sustainable development [2]. The most frequently identified key (supra-professional) competencies of sustainable development: predictive competence, strategic thinking, critical thinking, cooperation / interpersonal competence and self-awareness [3]. This list of competencies is becoming no less important for the formation at universities than the formation of professional competencies, which causes the need to search for new didactic tools $[4,5]$.

On the other hand, in May 2018, the President of the Russian Federation signed a decree "On national goals and strategic objectives for the development of the Russian Federation for the period up to 2024" [6]. One of the goals of the Education project concerns the creation of a digital educational environment (LMS) that will ensure the safety, quality and accessibility of modern education. LMS allows you to implement areas that are in demand in education: joint activities of students, personalization of activities, choice of formats and tools, fixing a "digital footprint" and, finally, operational analytics. Also, at present, more and more attention in the pedagogical process is paid to interactive technologies of project activities and technology "inverted classroom", which are the key components of the educational event as a form of learning. The implementation of educational events contributes to the manifestation of the activity and initiative of students, the disclosure and development of communicative competencies, systemic and critical thinking, information management, interaction with others in various forms of group activity.

In addition, in the Federal State Educational Standard of Higher Education $(3++)$ of the Russian Federation in the direction of training 44.04.01 Pedagogical education (bachelor's level), the general professional competence of OPK-2 is established - the ability to participate in the development of basic and additional educational programs, to develop their individual components 
(including using information and communication technologies). We believe that the data obtained during the design and implementation of educational events ("digital footprint") will expand information about the student, contribute to the development of human potential and individualization of the educational process, taking into account his interests. Participation in the educational event will contribute to the formation of not only supra-professional (key, universal) and general professional, but also professional competencies of students.

Purpose of the study: to design, implement an educational event in a digital environment for students of a pedagogical university and analyze its results in the context of the concept of competencies for sustainable development.

\section{LITERATURE REVIEW}

Education for sustainable development aims not only at addressing environmental sustainability issues, but also at social and economic issues [7]. Students of pedagogical directions today, tomorrow will become teachers, for the purpose of which the development and translation of students' competencies will take place in the interests of sustainable development [8]. Ensuring the capabilities of universities in the formation of the competencies of future teachers in the interests of sustainable development involves the introduction of project-based learning, interactive technologies, the variability of their implementation, including in the digital educational environment. These opportunities are noted in the work of KT Schmitt, as one of the points for solving educational problems for the implementation of sustainable development measures [9].

The use of educational events as a form of implementation of the educational process at the university is considered in the study by M. Sharples and his colleagues, devoted to the applied aspects of the implementation of educational activities [10]. P. Gossman, T. Stewart, M. Jaspers, B. Chapman conducted a small study $(\mathrm{n}=56)$, the essence of which was that students worked on educational problems using web scripts. Approbation of problem-oriented learning gave positive results [11]. K.Y.E. Loh, S.W.L. There, in his research, he talks about the willingness of teachers to use online technologies in the educational process [12].

An event must necessarily contain an activity, a set of actions for the preparation and implementation of the event. In the event-driven approach, the unit of design is an educational event. The design and implementation of educational events in vocational education are based on the research of N.V. Volkova (ontological aspects of the event-driven approach in education) [13], M.Yu. Zhilina, M.M. Mirkes (tutoring in an educational event) [14, 15], M.P. Prokhorov (on the role of this form of education in the development of competencies of university students) [16]. The technology of designing an educational event is described in the works of N.V. Volkova, M.P. Prokhorova, O.I. Vaganova, S. Dovbysh [16, 17, 18]. The experience of implementing educational events at universities is presented by N.V. Volkova, D. Fassi, A. Rebaglio, A. De Rosa [16, 19].

This paper is based on M.M. Mirkes and N.V. Fly, who interpret it as "a way of initiating the educational activities of students, active inclusion in various forms of educational communication, interest in the creation and presentation of products of educational activities, the formation of the competence of educational activities." responsible choice, taking a subject position in relation to oneself and one's educational results" [15].

An educational event, in contrast to a traditional lesson (lesson), as a perfect action, has three aspects of its implementation: result (the student has learned something), product and effect (strengthening of this action through feedback).

The use of the form of the educational process in the development of competencies for sustainable development in a pedagogical university is determined by several important points:

- in the educational event, the use of traditional educational tools - lectures and seminars is minimized. For the most part, this form involves learning by doing;

- the focus of the educational event on the development of the entire range of competencies. When preparing and conducting an educational event, a wide range of over-professional competencies develops, a pedagogical culture is instilled, and stable relations are formed in a group of students;

- educational activities contribute to the formation of professionally significant competencies, as well as individualization of training and the development of students' subjectivity.

\section{MATERIALS AND METHODS}

The experimental search work took place on the basis of the Ural State Pedagogical University (Yekaterinburg) from January 15 to March 1, 2021. The educational event was implemented within the framework of the Decade on the History of Pedagogy and Education, which is dedicated to the teachers of the anniversary.

The design is based on the concept proposed by N.V. Volkova [16] and includes the following stages: preproject, project development, project implementation, reflection, after project activity (Table 1).

The COREapp online platform chosen to create an educational event meets the above requirements: result - 
Table 1. Stages of designing an educational event

\begin{tabular}{|c|c|}
\hline Stage & $\begin{array}{l}\text { Stage description } \\
\end{array}$ \\
\hline \multirow[t]{3}{*}{$\begin{array}{l}\text { Pre-project } \\
\text { preparation }\end{array}$} & $\begin{array}{l}\text { Determination of relevance: the legacy of the classics of pedagogical thought is important for future } \\
\text { teachers to comprehend not only for the development of professional knowledge, but also for the } \\
\text { development of supra-professional competencies and the development of the personality culture of } \\
\text { students. }\end{array}$ \\
\hline & $\begin{array}{l}\text { Problematization. The number of hours for the discipline "Pedagogy" is decreasing every year, the } \\
\text { number of classes devoted to the history of pedagogy is not enough. The gap indicated above needs } \\
\text { to be filled. }\end{array}$ \\
\hline & $\begin{array}{l}\text { - Conceptualization. This event is aimed at the implementation of civil, patriotic education of Ural } \\
\text { State Pedagogical University students, at increasing the level of knowledge on the history of pedagogy } \\
\text { and education, at attracting the attention of students and staff of the Ural State Pedagogical University } \\
\text { to the heritage of domestic and foreign teachers. }\end{array}$ \\
\hline $\begin{array}{c}\text { Project } \\
\text { development }\end{array}$ & $\begin{array}{l}\text { Stage } 1 \text { - development of a regulation on holding a competition of interactive lessons on the COREapp } \\
\text { educational platform }\end{array}$ \\
\hline \multirow{3}{*}{$\begin{array}{l}\text { Implementation of } \\
\text { the project }\end{array}$} & Stage 2 - teaching students to create lessons on the COREapp educational platform \\
\hline & Stage 3 - development of the regulation on the quiz "History of pedagogy in persons" \\
\hline & Stage 4 - creation of the Quiz "History of Pedagogy in Persons" \\
\hline \multirow[t]{3}{*}{ Reflection } & Stage 5 - training of tutors accompanying the event in the online environment \\
\hline & $\begin{array}{l}\text { Competition of interactive online lessons among students-developers (presentation of interactive } \\
\text { lessons about teachers-anniversaries; testing and examination of interactive lessons) }\end{array}$ \\
\hline & $\begin{array}{l}\text { Conducting an online quiz "The history of pedagogy in faces" among students, pedagogical areas of } \\
\text { training }\end{array}$ \\
\hline $\begin{array}{l}\text { Post-project } \\
\text { activities }\end{array}$ & Organization of feedback by student tutors during the quiz \\
\hline
\end{tabular}

product - reflection; and also corresponds to the key characteristics of the educational environment: openness, variability, redundancy, orderliness.

The technology of designing an educational event included 28 students of the 3rd year, the direction of preparation: 03.44.05 Pedagogical education, who were trained to create interactive lessons on the educational platform https://coreapp.ai/.

To design an educational event, we chose the online platform https://coreapp.ai/. Opportunities pre-project, project development, project implementation, reflection, post-project activities that can be used to design an educational online event: text;

- creation on the platform and design of blocks of

- creation of hyperlinks to external resources on the platform;

- grouping and inserting media files, tables and diagrams into the lesson context;

- the ability to add files during the lesson with completed tasks;

- creating question and answer forms for interactive exercises;

- feedback form from the teacher;

- detailed monitoring of activity on the platform;

- user-friendly platform interface.
The Activity Builder interface consists of three blocks:

1. Information blocks: "Text", "Instruction", "Media file", "Image", "Exercise", "Document".

2. Tasks and tests: "Test", "Open question", "Classification", "Question with auto-check", "Fill in the blanks", "Dialogue simulator".

3. Reflection: "Poll", "Feedback".

It should be noted that recently the developers have paid great attention to the settings of the results monitoring system. The ability to upload the results of the lesson in Excel format makes it possible to draw better conclusions, based not only on the correctness of the assignments, but also on the time spent on passing the material by the student.

\section{RESULTS}

The students were divided into mini-groups, each group chose a teacher-hero of the day (R. Steiner, M. Montessori, M. N. Skatkin, V. A. Slastenin, L. V. Zankov, Sh. A. Amonashvili, E. A. Yamburg, etc.). The groups independently developed an interactive lesson on the CORE educational platform, and then presented it to the expert community. The quiz is available at https://coreapp.ai/app/player/course/6016dd63653c470a ec3d1537.

According to the results of the expert assessment, the average score of the developed classes is 4.58 (on a fivepoint scale), which indicates a sufficient level from the 
substantive and methodological side. In general, the experts noted the fascinating format of the classes, the presence of interactive interaction with the audience, various forms of material presentation and control of knowledge assessment, interesting visualization, dynamism.

The quiz "History of pedagogy in faces" was offered to students studying in the directions "44.03.01 (05) Pedagogical education" and "44.03.02 - Psychological and pedagogical education".

Goals and objectives of the quiz:

- attracting the attention of students to the works and achievements of the classics of pedagogical thought;

- increasing the activity, motivation and involvement of students in the educational process;

- development of communicative competencies (feedback, reflection, discursive competence, negotiations) of students.

Participation in the Quiz was assessed according to the following criteria:

- $\quad$ the number of passing interactive lessons;

- $\quad$ quality of performance of all tasks of the lesson;

- the total number of points scored based on the results of the control block.

To accompany the quiz, tutors were identified from among the senior students who accompanied this event in the online environment.

234 students of the Ural State Pedagogical University took part in the quiz, 49 of them passed all 10 tasks of the quiz. The prize-winners were also distributed depending on the number of points scored.

Reflection is an important point in organizing and conducting an educational event in an online format. Reflective assessment was conducted with student lesson creators for the Quiz, with student participants in the Quiz and student tutors who accompanied the event.

The creator students appreciated the experience gained: $87 \%$ of students perfectly mastered the online constructor; $74 \%$ - interested and carried away by designing lessons in an online format; $93 \%$ - consider the experience gained to be important for the further development of the teacher's ICT competence; 54\% noted in their essays that they felt themselves in the role of a teacher, they can predict their future professional activities. All students noted the importance and effectiveness of the organization of team interaction, the opportunity to highlight the strengths and roles of each of the group members. In addition, in the essay, the students wrote that during their work, all team members had a high level of motivation not only to complete the task, but to make it as interesting and unusual for the participants as possible and attractive for experts.

Students participating in the Quiz indicated an interesting format $(76 \%)$, the presence of interactive tasks $84 \%$, video clips $(72 \%)$ and feedback $(81 \%)$ in each lesson. $67 \%$ of student participants were interested in the online platform on which the Quiz lessons were posted, decided to develop digital competencies in working with the proposed platform and other digital tools for organizing the educational process.

7 students-tutors were responsible for accompanying the Quiz, who commented on the answers of the participants, helped to choose the order of the Quiz lessons, and also gave feedback and conducted reflexive sessions. Despite the fact that reflective sessions were held online, they allowed maintaining a high level of communication productivity.

The feedback received from the participants and the level of expert assessment of the developed educational events by students gives an idea of the effectiveness of the technology application. On the one hand, the high assessment of experts reflects the professionalism of future teachers. On the other hand, indicators of competencies for sustainable development (supraprofessional competencies), reflected in the essay, demonstrate the reflection of students on the impact on this type of competence.

An educational event is a form of organization of the educational process, which combines a wide range of classroom and extracurricular activities, which has a positive effect on the results.

\section{CONCLUSION}

The study demonstrates the existence of a wide range of possibilities for implementing event-based learning in a digital educational environment, using the "inverted classroom" technology, in which future teachers could immerse themselves in the atmosphere of a modern teacher's work.

Designing educational events in an online format in higher pedagogical education allows students to see their capabilities in practice at different levels and in different roles: from creator and participant to tutor. At the same time, this is an experience for the development of not only professional, but also supra-professional competencies of future teachers that are important for sustainable development.

The creation of interactive classes on the COREapp online platform allows students, future teachers, to develop ICT competencies, competencies in the field of interpersonal relationships and communications, predictive competencies and teacher self-awareness. It should be noted that competencies in the interests of sustainable development for teachers of the 21 st century are one of the key ones, since the solution of problems in 
the field of ecology, economics and social life depends on their future practical activities.

\section{ACKNOWLEDGMENTS}

The study was carried out with the financial support of the Russian Foundation for Basic Research in the framework of scientific project No. 19-29-07435

\section{REFERENCES}

[1] E. M. Waltner, K. Scharenberg, C. Hörsch \& W. Rieß, What teachers think and know about education for sustainable development and how they implement it in class. Sustainability, 12(4) (2020) p. 1690 . DOI: https://doi.org/10.3390/su12041690.

[2] UNESCO. Education for sustainable development: learning objectives.Brasilia: UNESCO Representation in Brazil, 2017. https://www.unesco.de/sites/default/files/201808/unesco_education_for_sustainable_developmen t_goals.pdf.

[3] A. Pesha Key competencies of university graduates to achieve sustainable development. E3S Web of Conferences. EDP Sciences, 291 (2021) 05005. DOI: https://doi.org/10.1051/e3sconf/202129105005.

[4] G. Tejedor, J. Segalàs, Á. Barrón, M. FernándezMorilla, M. T. Fuertes, J. Ruiz-Morales, \& À. Hernández, Didactic strategies to promote competencies in sustainability. Sustainability, 2019, 11(7), 2086.2 DOI: https://doi.org/10.3390/su11072086

[5] R. Lozano, M. Barreiro-Gen, F. J. Lozano, K. Sammalisto, Teaching sustainability in European higher education institutions: Assessing the connections between competences and pedagogical approaches. Sustainability, 11(6) (2019) p. 1602. DOI: https://doi.org/10.3390/su11061602.

[6] Decree of the President of Russia "On national goals and strategic objectives of the development of the Russian Federation for the period up to 2024". http://kremlin.ru/acts/news/57425.

[7] E. Sinakov, J. Boeve-de Pauw, M. Goossens, \& P. Van Petegem, Academics in the field of Education for Sustainable Development: Their conceptions of sustainable development. Journal of cleaner production, 184 (2018) pp. 321-332. DOI: https://doi.org/10.1016 / j.jclepro.2018.02.279.

[8] M. Hofman, Sustainable development in the Finnish teacher education-Political rhetoric or reality. J. Educ. Sustain. Dev, 9(2) (2015) pp. 213-228. DOI: https://doi.org/10.1177\%2F0973408215588255.

[9] C. Schmitt, A. Bassen., G. Müller-Christ, Sustainable Development at Higher Education Institutions in Germany: Advances, Challenges, Examples. HEAD'19. 5th International Conference on Higher Education Advances. Editorial Universitat Politècnica de València, pp. 1009-1017 (2019). DOI: http://dx.doi.org/10.4995/HEAd19.2019.9216

[10] M. Sharples, A. Adams, R. Ferguson, G. Mark, P. McAndrew, B. Rienties, \& D. Whitelock, Innovating pedagogy 2014: exploring new forms of teaching, learning and assessment, to guide educators and policy makers. The Open University, (2014). https://www.learntechlib.org/p/149392/.

[11] P. Gossman, T. Stewart, M. Jaspers, B. Chapman, Integrating web-delivered problem- based learning scenarios to the curriculum. Active Learning In Higher Education, 8(2) (2007) pp. 139-153. DOI: https://doi.org/10.1177\%2F1469787407077986

[12] K.Y.E. Loh, S.W.L. Tam, The role of emotionality in teacher change: the case of Chinese language teachers in Hong Kong. Teacher Development in Education, 21(3) (2017). http://www.tandfonline.com/doi/full/10.1080/1366 4530.2016.1266381.

[13] N.V. Volkova, Educational events: signs and characteristics. Bulletin of the North-Eastern Federal University named after M.K. Ammosova, 7(1) (2010) pp. 78-82.

[14] M. YU. ZHilina, Educational event: reading options. Organization of tutor support in educational institutions: content, regulation and standardization of the tutor's activities: materials of the All-Russian scientific and methodological seminar "Standards of tutoring: theory and practice", Moscow, APKiPPRO Publ. (2019) pp.152-158.

[15] M. M. Mirkes, N. V. Muha, Educational event as a tutor's practice. Eventfulness in education and pedagogical activity, 43 (2010) pp. 91-99.

[16] M. P. Prohorova, O. I.Vaganova, N. A. Rumyanceva, Methodology of designing an educational event at a university. Problems of modern teacher education. Series "Pedagogy and Psychology": collection of scientific papers.Yalta, RIO GPA Publ., 59(4) (2018) pp. 153-157.

[17] N. V. Volkova, Technology for designing educational events. Education and Science, 19(4) 92017) pp. 184-200. DOI: https://doi.org/10.17853/1994-5639-2017-4-184200.

[18] S. Dovbysh, Event-based approach in a teacher's work: an open educational technology "Eventresource mapping". SHS Web of Conferences. EDP Sciences, 55 (2018) p. 03010. DOI: https://doi.org/10.1051/shsconf/20185503010.

[19] D. Fassi, A. Rebaglio, A. De Rosa, Designing a cultural event as an inclusive educational activity. The Design Journal, 20 (2017) pp. S988-S999. DOI: https://doi.org/10.1080/14606925.2017.1353043. 